\title{
Exteriorization Site
}

National Cancer Institute

\section{Source}

National Cancer Institute. Exteriorization Site. NCI Thesaurus. Code C77685.

The site of the surgical exposure of an internal organ or tissue. 